Estudios sobre armas antiguas, arte militar y vida cultural en oriente y occidente XXXII (2012), pp. 69-86

ISSN : 0436-029X

doi: $10.3989 /$ gladius.2012.0004

\title{
CASTING MOULD WITH RELIEF OF ARMED HORSEMAN FROM CORDOBA
}

\author{
MOLDE PARA FUNDICIÓN CON RELIEVE DE JINETE ARMADO \\ PROCEDENTE DE CÓRDOBA
}

POR

\author{
Rafael Hidalgo Prieto ${ }^{1}$
}

\begin{abstract}
Resumen
In this paper we present an unpublished plaque decorated with an armed horseman found in the archaeological site of Cercadilla in Cordoba. The piece, made of calcarenite, is carved in hollow relief, which together with some of its defining features, allow us to identify it as one of the valves of a casting mould, which was used to produce ornamental items of unknown purpose. The cavalryman's panoply especially the helmet, together with the historicarchaeological context from which it comes, allow us to date it to between the second half of the sixth century and the seventh centuries A.D., and identify the cavalryman as a member of the elite of the Visigoth period.

En este trabajo presentamos una placa inédita decorada con un jinete armado procedente del yacimiento arqueológico de Cercadilla en Córdoba. La pieza, de calcarenita muy depurada, está labrada en hueco relieve lo que, unido a algunas de las características que la definen, permite identificarla como una de las valvas de un molde de fundición, destinado a la elaboración de elementos ornamentales de uso indeterminado. La guarnición que porta el jinete, especialmente en lo concerniente al casco, en relación con el contexto histórico-arqueológico del que procede, permite proponer su datación entre la segunda mitad del s. VI y el s. VII d.C. y su identificación con un personaje-tipo de la elite de época visigoda.
\end{abstract}

\section{Keywords - Palabras Clave}

Casting mould; Cavalryman; Visigoth panoply; Cercadilla; Cordoba.

Molde de fundición; Caballero; Armamento visigodo; Cercadilla; Córdoba.

\section{ARCHAEOLOGICAL CONTEXT OF THE PIECE}

The plaque, currently held in the collection of the Archaeological Museum of Cordoba ${ }^{2}$, was discovered during excavations carried out at the archaeological site of Cercadilla in 1993. It was found in a cut made in the palace baths, at a superficial level.

In view of the unusual nature of the piece and starting from the fact that it is not associated with any defining chronostratigraphic context, it is necessary to analyse the occupational sequence of Cercadilla, at least briefly, before embarking on its study and thus define which of the periods documented in the site it can be ascribed to.

1 Seminario de Arqueología, Facultad de Humanidades, Universidad Pablo de Olavide de Seville, Carretera de Utrera Km. 1, E-41013, Seville. Email: rhidpri@upo.es.

2 Registration $\mathrm{N}^{\text {o }}$; 1197; catalogue number: Cer'93/Sector 18/C. 13. 
In our opinion, and in keeping with the image it depicts, the plaque can be very roughly dated to Late Antiquity or the Early Middle Ages, a period when Cercadilla was heavily populated. After the construction of the tetrarchic imperial palace found at the site ${ }^{3}$, we know that the ancient palatine complex was reused as a place of Christian worship from at least the mid-sixth century ${ }^{4}$, although this change of use may have occurred earlier, around the middle of the fourth century. A key figure in this respect is Ossius, bishop of Cordoba and adviser of Constantine who, more than anyone else, would have had the authority to change the purpose of the building from civic to religious, giving it the function of a martyrium or memoria.

The place of worship that was established as a result of this became transformation without doubt one of the most important Christian enclaves of the city, as demonstrated by, amongst other things, the epigraphic evidence referring to the burial there of two previously unknown bishops - Lampadius and Samson - in Late Antiquity. Moreover, this Christian place of worship was not abandoned with the emergence of Al-Andalus, but survived as a major centre of the Mozarab community, which during the Caliphate coexisted with one of the Islamic districts on the outskirts of the city.

\section{DESCRIPTION OF THE PIECE}

The piece in question (figs. 1-2) is a plaque of fine-grain calcarenite which is $14.1 \mathrm{~cm}$. wide, $11.1 \mathrm{~cm}$. high at its maximum preserved height and $2.5 \mathrm{~cm}$ thick. The obverse displays the decoration, consisting of part of an armed cavalryman, partially preserved. It has been carved in counter-relief, to a depth of around 1-2 $\mathrm{mm}$ in places. The cavalryman and what remains of his mount have been carved in a very rudimentary fashion, in places consisting only of very simple grooves, which, together with the rough execution of the main elements, make the image difficult to interpret.

The cavalryman is wearing simple armour which has been represented simply as an irregular rectangular or rhomboidal grid created by roughly scratched horizontal and vertical lines. The cuirass reaches, at the most, just past the elbow, to the beginning of the forearm, while the lower part of it reaches at least to the beginning of the thighs, while anything below that has been lost. At the waist there is a broad belt, a common way of relieving the shoulders and the neck of some of the weight of the armour (Quesada, 2008: 252), which is emphasised by thicker and deeper grooves to indicate squares. At the neck are two incised lines that should be considered separate from the armour and which represent a ribbon or neck ring.

An interpretation of this garment used as body armour, because of the way it is depicted and the difficulties implicit in its schematic representation, can consider two possibilities. The first is that it was a doublet of overlapping scales, in the tradition of the lorica squamata, and the second that it was chainmail, in the tradition of the lorica hamata. Of these two possibilities, it seems more plausible that it was chainmail, since scales, being more rigid, tended to cover just the torso, as depicted in the graffito of the clibanarius of Dura Europos (Baur, Rostovtzeff y Bellinger, 1933: P1. XXII.2 and Rostovtzeff et alii, 1952: fig. 6), and did not extend to the arms, because they would adversely affect mobility. Furthermore, had the artist wished to depict scale armour it would have made more sense to depict the scales, even if only roughly, while mail, since it consisted of very small rings, was more difficult to show in

\footnotetext{
3 On the palace of Cercadilla and the previous phases of occupation, see Hidalgo, 1996.

4 On the occupation of Cercadilla at this time, see Hidalgo, 2000 and 2002; Hidalgo and Fuertes, 2001; Ortiz, 2003 and Fuertes and Hidalgo, 2005.
} 


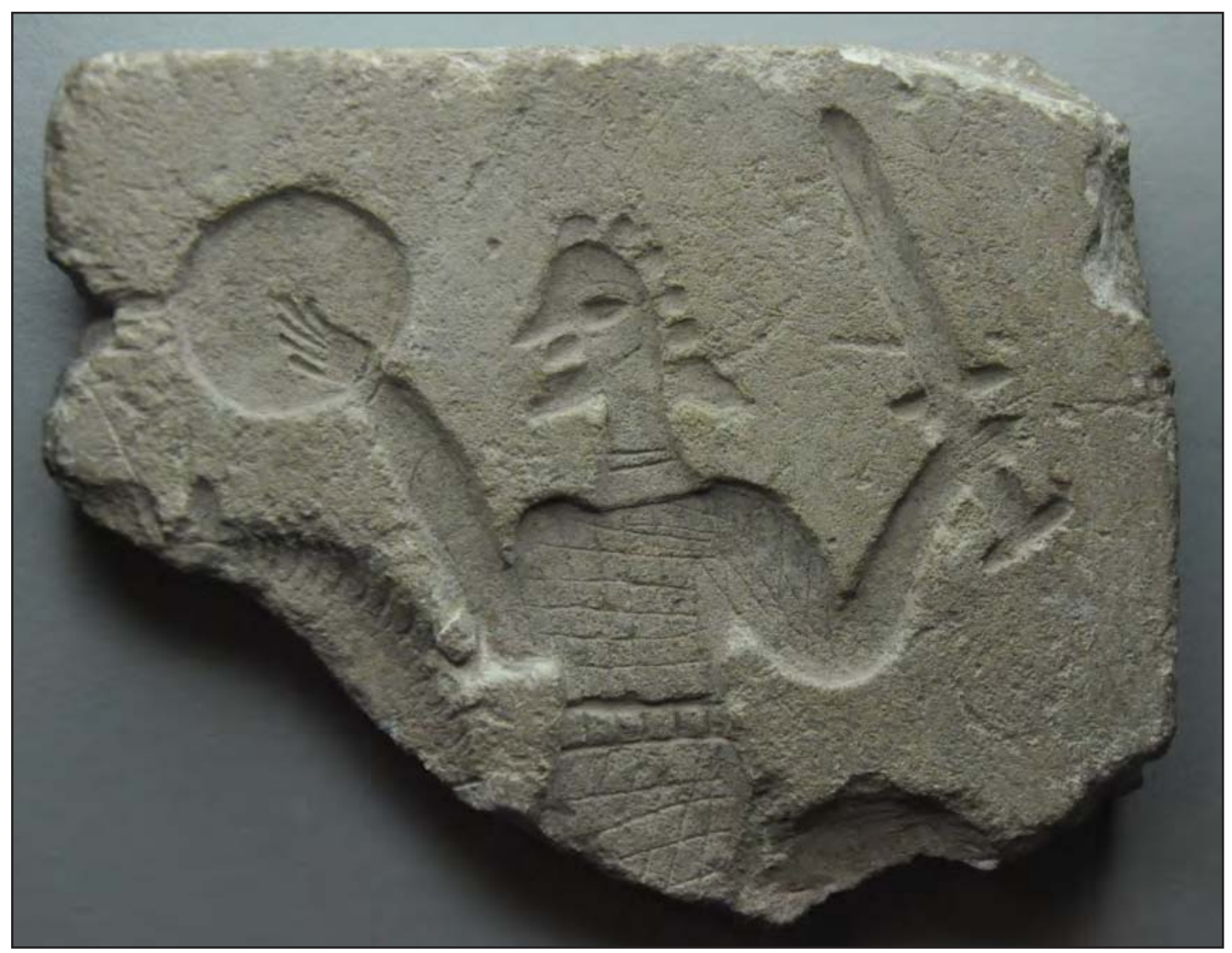

Figure 1. Plaque of the armed cavalryman from Cordoba.

detail. This problem could be overcome by the conventional device of a grid of crossed lines. In addition although both types coexisted until medieval times, chainmail was more widely used in the cavalry from the Later Roman Empire onwards, especially in the Western Empire (MacDowall, 1995: 12). However, it cannot be ruled out that it was a doublet of scales which, although less frequent, is documented in Hispanic Late Antiquity (Vizcaíno, 2008).

The arms, raised to the height of the head, bear a sword in the left and shield in the right. In keeping with the overall simplistic style of the piece, the small shield is represented by a circle, held by a hand but in a not very naturalistic way, without the necessary hand grip. There is a double line on the right wrist, which may be a bracelet or wrist band ${ }^{5}$, while a very shallow double groove can be observed on the forearm, unassociated with the edge of the cuirass, with which it is not connected. This double groove could be a bracelet or similar ornamental element, although because of where it is, and above all because of its position and shape, it may just be a rough indication of the reins. In this case they can be held with the arm that is carrying the shield, that is, the one that needs less freedom of movement during combat. However, if the cavalryman was using stirrups, he would not have needed reins ${ }^{6}$.

5 This double groove could also indicate the garment that was worn under chainmail during the various periods when this was used. It was both a piece of clothing and a protective garment to avoid the chainmail coming directly into contact with the body when the wearer was struck in battle.

6 For arguments against the use of stirrups in Europe before the mid-eighth century: Ardanaz, Rascón and Sánchez, 1998: 429-430. 


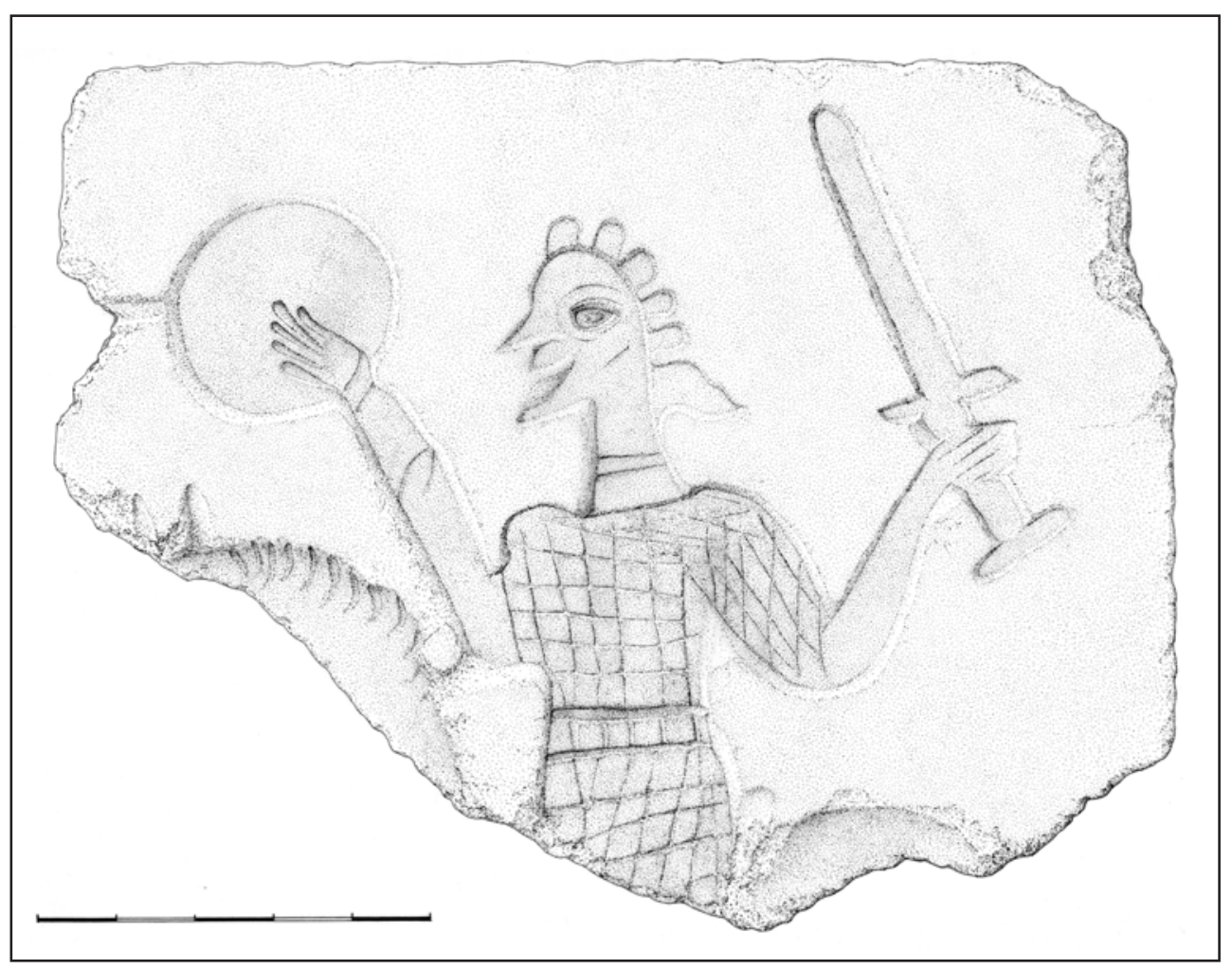

Figure 2. Drawing of the plaque (E. Conlin).

To the left edge of the shield a rectilinear groove is preserved, about $1 \mathrm{~mm}$. deep, leading towards the edge of the piece, but largely lost where the plaque is broken, which we shall look at again later in relation to the way in which the plaque was used.

The sword held in the left hand is a straight sword, slightly shortened, probably as a result of adjusting the design to the near edge of the plaque on which it was carved, with no indication of a fuller or fullers in the blade. Despite the shortcomings in the rendering of the sword, it can be perfectly identified a typical, double-edged long sword used by heavy cavalry, with a double-edged and not very pointed blade, used to cut and strike, but not as an rapier. The absence of the usual central fullers may be because the design has been simplified, or because it is associated with the long Visigoth sword, which did not have a central fuller (Soler del

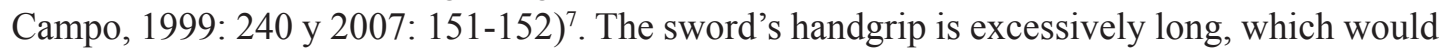
make it difficult to wield effectively with a single hand, which can be attributed to the generally rough execution. It has a typical straight cross-guard with a square cross-section, of the kind which, because of it was so simple and effective, remained in use from the Roman era until the end of the Middle Ages (Soler del Campo, 2001: 344). The pommel is simple and straight, also clearly emphasised but with no distinctive elements, perhaps once again because it has been executed in a rudimentary fashion.

7 The Emirate sword whose origin is attributed to the province of Cordoba (Canto, 2001) did not have a central fuller either, and had a rectangular pommel although, as will be seen later, other details distance the sword carried by the Cercadilla cavalryman from the swords of Al-Andalus and its panoply in general. 
The fact that the hilt appears to be disproportionally large compared with the blade could be seen as an attempt to endow the action with a certain perspective and movement, with the aim of showing the sword's movement while attacking, slashing it forwards, in the direction of the observer. However, the overall simplicity of the decoration rather suggests it is an imprecise rendering in which, as has been said, the blade was shortened to make it fit the slab on which it was carved.

The cavalryman wears an original helmet which displays various elements of interest that provide clues to help its identification. The pointed, excessively long nose suggests that the helmet has a nose guard, while near the eye - carved as an almond-shaped hollow with a small, barely perceptible projection to indicate the pupil- there are two shallow grooves, one over it, indicating the edge of the helmet above the eye, and the other on the jaw line, representing the cheek piece, used to hold the helmet in place and protect the ears and face. The long, pointed chin also seems to reflect the roughly carved point where the cheek piece is fixed to the helmet.

Attached to the bowl of the helmet is what is evidently a plume or crest, depicted roughly, in the same way as the rest of the decoration, which ends at the nape of the neck in a larger appendage. This could be the end of the plume itself or a neck guard, or even an aventail. However, the curved shape of this detail, which has a wavy appearance, and its width, suggests that the first of these possibilities is more likely.

The horse on which the cavalryman is mounted has almost disappeared. Only a little of the head and neck has been preserved, together with the rump. Nevertheless, from the small part of the neck that has been preserved, particularly the mane, it seems to have been carved in a fairly detailed and naturalistic way. On the back of the saddle a small projection can be seen which, because of its position, could very well be the cantle of the saddle, but because it coincides with a small fracture we cannot be entirely sure.

The back of the plaque (fig. 3) has a depression around the whole of the perimeter, but what is particularly noticeable is a series of irregular incised lines, of varying depth. These

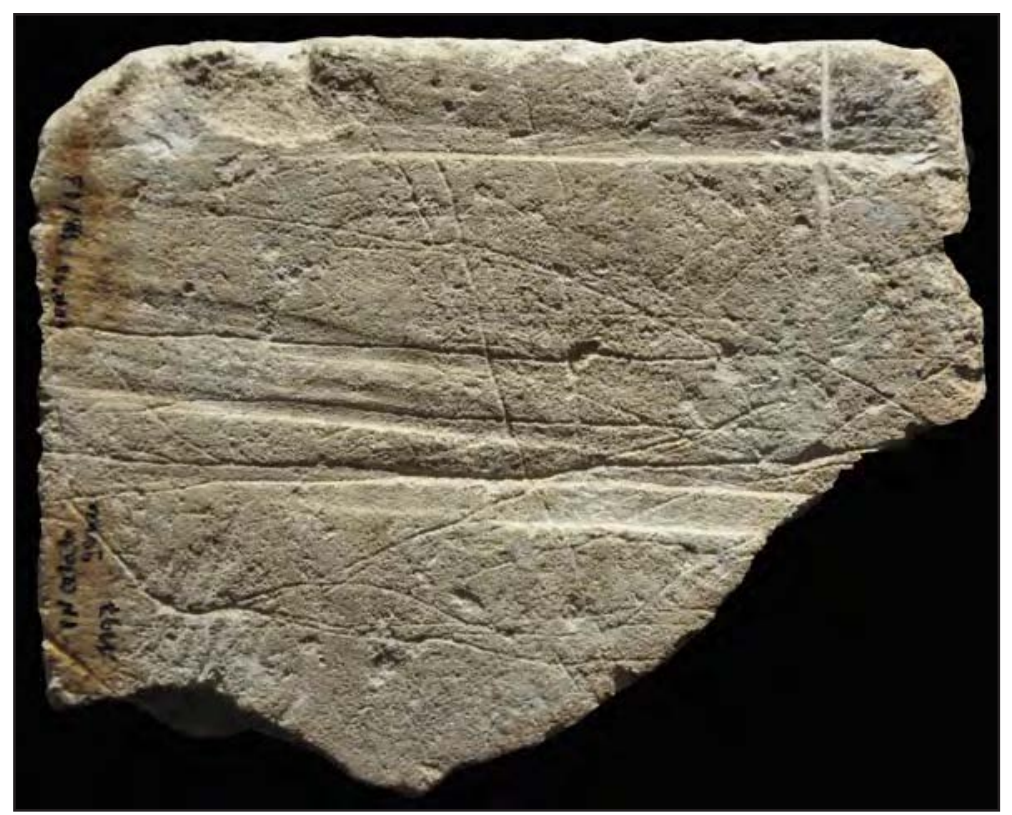

Figure 3. Reverse of the plaque. 
lines are mainly across the width of the piece, but not exclusively, since some run from top to bottom. One at the upper edge is especially interesting: it is deeper than the others, and can be interpreted as a sign of wear.

\section{INTERPRETATION OF USE}

One of the first questions that a study of the plaque provokes, even before we come to the problem of dating it, is what it was used for. The first possibility that reasonably comes to mind is that it is an ornamental plaque designed to be embedded in a wall or similar structure, on its own or as part of a larger scene. However, cavalrymen were very rarely portrayed in the late antique and early medieval sculpture of the Iberian Peninsula ${ }^{8}$ and never appear with a complex panoply as in this case. Although there are some examples of cavalrymen, mainly unarmed or bearing very simple offensive weapons, also very roughly depicted, they are very different from the one portrayed on the Cercadilla plaque. In particular mention should be made of the very roughly carved - and unarmed - faithful horseman on the southern cymatium-impost of the triumphal arch of church of Pedro de la Nave (Schlunk y Hauschild, 1978: 223-227, taf. 132.b), the two horsemen facing each other framed in arches in the central hall of Santa María del Naranco (García de Castro Valdés, 1997: 95) and the armed horseman, also very roughly carved, of San Miguel de Villatuerta (Navarre) (Arbeiter and Noack-Haley, 1999: 362-365, taf. 113). Neither do they appear in the decorated slates, in which any similarity is due almost entirely to the rudimentary style (Barroso y Morín, 2007: 39).

Furthermore, an important factor to take into account is that, even in very rudimentary images, even more roughly carved than the one that concerns us here, late antique and early medieval decorative sculpture, particularly those depicting figurative motifs, are not rendered in counter relief, which is virtually non-existent, with very few exceptions, such as the singular chi rho of the plaque of Nuestra Señora de la Hermida de Quiroga (Lugo) (Schlunk y Hauschild, 1978: 139-140, taf. 32).

Another aspect that should be taken into account is that the plaque is very small, and so, therefore, is the ornamental motif. Hispanic decorative sculpture is rarely so small and the piece could not be inserted at any great height, since it would not be visible, particularly in the case of the lightly engraved lines representing certain details such as the pupil, the cheek piece, the bracelet/reins and the left hand.

However, the dimensions do suggest that the plaque could be related with the late antique tradition of stamped bricks, in which cavalrymen were sometimes used as a decorative motif, albeit infrequently. However, both the material and the iconography of the cavalryman and, once again, the fact that it is depicted in counter relief, mean this possibility has to be ruled out too.

In view of what we have seen so far, another possibility that should be considered is that the plaque could be one of the valves of a casting mould ${ }^{9}$.

Evidence in support of this argument would be, first of all, the previously mentioned groove connected to the shield, which could have been the channel through which the metal was

8 Of the abundant studies we have today on late antique and early medieval decorative sculpture in the Iberian Peninsula, see in particular Schlunk and Hauschild, 1978; Cruz Villalón, 1985; Arbeiter and Noack-Haley, 1999; Barroso and Morín, 2007; Vidal, 2005; Sánchez, 2006 and Caballero and Mateos, 2007.

9 In the Archaeological Museum of Cordoba there is a mould for casting Islamic lamps ( $n^{\circ}$. inv.: DJ032908/4) made from the same material as the plaque. I should like to thank C. Costa for this information, and other very interesting comments about the piece. 
poured, most probably bronze, or the vent. Similarly, the aperture on the edge of the plaque, which coincides with the end of the channel, may not simply be damage to the edge, but could have been carved specifically to act as funnel.

The incised lines on the back may have been used to give the mortar a better hold, allowing the plaque to be embedded in a building material, like a similar solution used in many periods with bricks and roof tiles. However, since in most cases these grooves are so shallow, it does not appear that they were designed to serve that purpose nor that they did in fact do so. It is more likely that they are signs of the wear traces produced by fine twine used to hold the two valves of the mould tightly together before pouring in the metal. In particular, the deepest groove preserved is in the upper part of the reverse, on the edge where wear would be greatest, which makes sense if this interpretation is correct.

The fact that there is no means of anchoring the other valve, normally present in moulds for producing pieces in the round, and the very flat relief of the piece that would be produced by casting, suggests that the reverse was flat, with no decoration. This means that the piece cast can be identified as an appliqué.

The fact that the cavalryman is carrying the sword in his left hand and the shield in his right also supports its interpretation as a mould. Although there are exceptions, images of armed cavalryman usually, irrespective of the period, naturally carry the sword in the right hand and the shield in the left, and this would be the case in the positive, if this really is a mould.

In order to confirm the possible use of the plaque as a mould we used it to make a plaster cast (fig. 4), which makes it possible to see what the piece cast from the mould would be like and whether such a result is plausible.

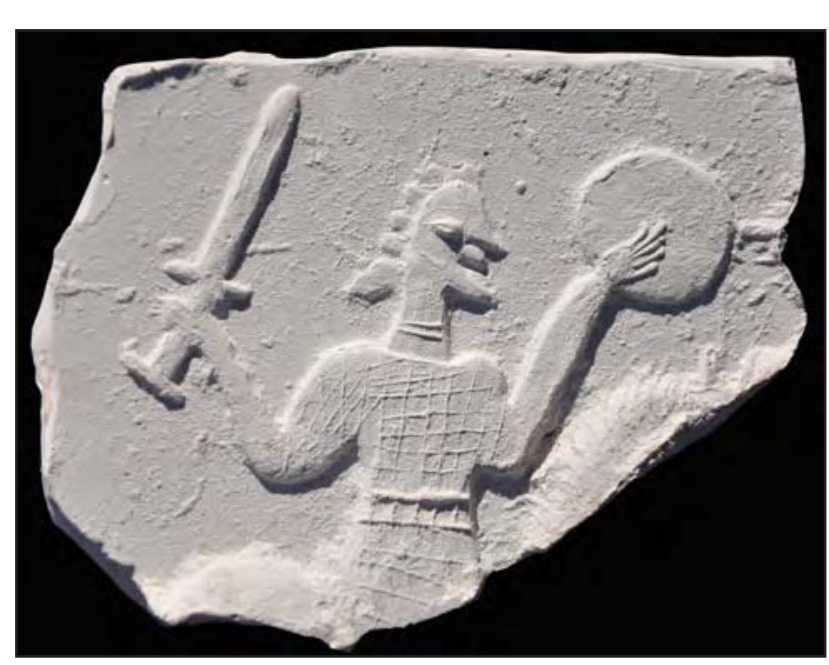

Figure 4. Positive

In the positive, a particularly striking detail is the eye (fig. 5), which really stands out. And the pupil, indicated by a fine groove, which can hardly be seen in the original because of the depth of the eyeball, is also clearer in the positive. In the same way, the marks of the helmet on the face, both the one above the eye and that indicating the cheek piece, are much clearer and therefore, more visible, in the positive than the negative.

In the positive, the helmet plume stands out, giving the bowl of the helmet greater depth and volume, while both elements look much flatter in the original. The fact that the plume is in direct contact with the bowl of the helmet and not separate, as might be more logical on the basis of the type of helmet depicted — vid infra - also makes more sense if it is a mould, because if the plume had been carved separately it would have been difficult to cast, and would also have created a fragile element in the resulting plaque that would have broken easily.

A detail that deserves special mention relates to the contact between the neck and the trunk. As in the case of the plume, the positive creates a better and more realistic impression of the cavalryman's volume, so that the trunk - and particularly the cuirass - stands out slightly 


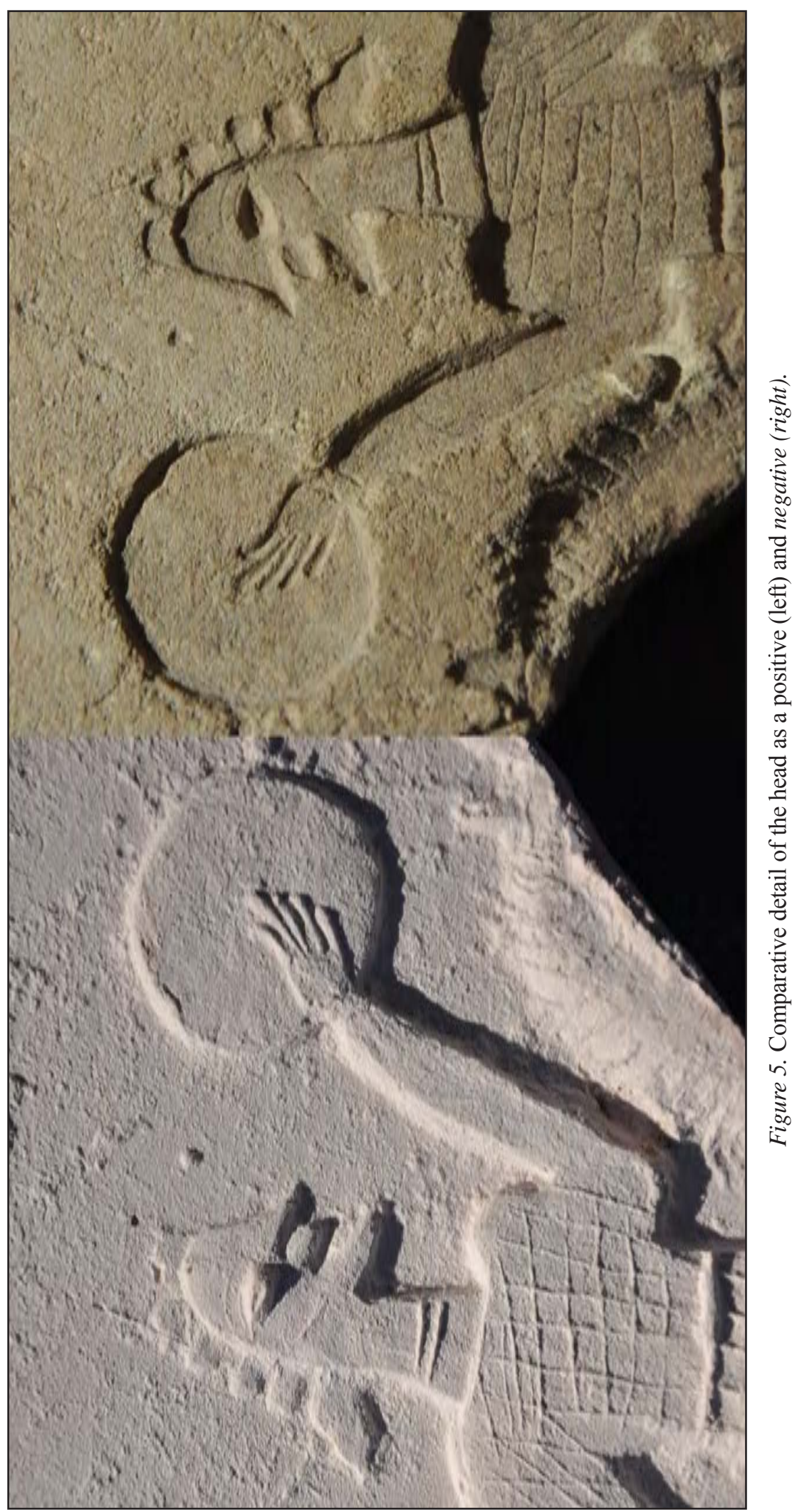

Gladius, X XX XII (2012), pp. 69-86. ISSN : 0436-029X . doi: 10.3989/gladius.2012.0004 


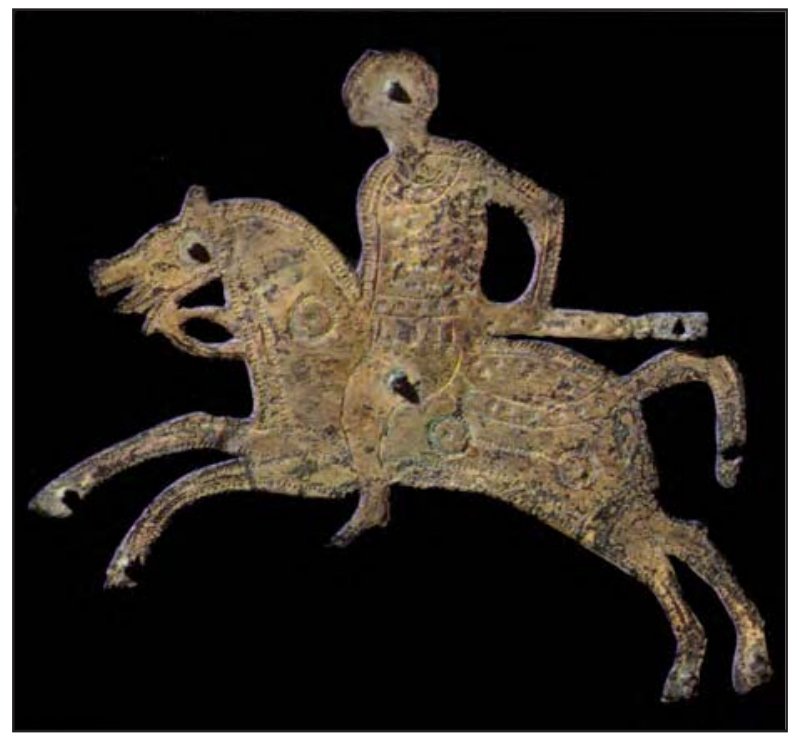

Figure 6. Stabio horseman (example from the Historisches Museum, Berna) (from: Hubert, 1968). from the neck. On the other hand, in the negative it is the neck that stands out artificially from the trunk, and the resulting image is much less natural.

Other aspects, although less obvious, that also support this interpretation are the hands, the belt and, in particular, the cantle, which can hardly be seen in the negative and is much more evident in the positive.

So, from what we have seen so far, the piece can be better interpreted as part of a casting mould than as an ornamental plaque. The mould is a unique example, because we have no metal pieces in the region that even remotely resembles this particular piece (vid. Ripoll, 1998). However, the use of the armed horseman - whether as a warrior or as a hunter- as a motif is not ex-

ceptional in European late antique and early medieval bronzes, as testified particularly by the Lombard horseman on the Stabio shield (fig. 6) or the openwork roundel depicting a Germanic warrior in the Badisches Landesmuseum in Karlsruhe (Germany) (fig. 7), both dating to the seventh century.

The purpose of the piece cast is difficult to determine with any certainty from the part that has been preserved, but would most probably have been used as an appliqué. Moreover, since it is a very flat relief it would seem reasonable to assume that it was used in the ornamentation of some item of sumptuous furnishing, although other uses cannot be ruled out, for example that it formed part of horse trappings or the decoration of a shield, as in the case of the Stabio horseman.

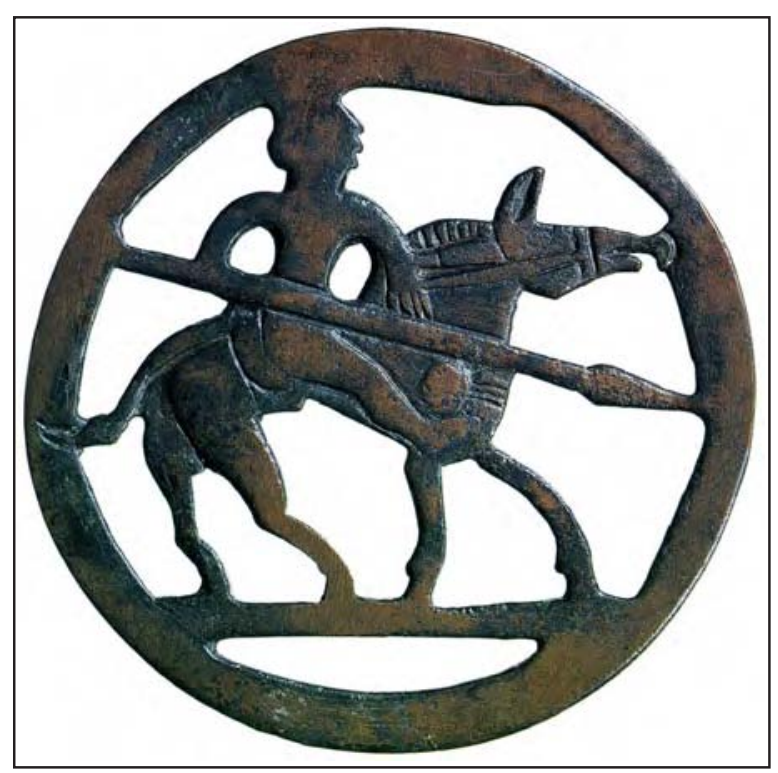

Figure 7. Germanic warrior (Badisches Landesmuseum, Karlsruhe, Germany) (from: Luzón and Sureda, 1997, fig. 337).

\section{STYLISTIC AND CHRONOLOGICAL ANALYSIS}

For stylistic and chronological purposes, the singular and exceptional character of the mould means its analysis needs to take in a broad timespan, which is determined by the 
stratigraphic context it comes from. As has been said, the plaque appeared near the surface, at a site occupied up to the time of the Caliphate ${ }^{10}$.

We can start by ruling out the possibility of the piece dating to the Islamic period ${ }^{11}$. Firstly it has to be remembered that Islamic iconography usually portrays light cavalry, since this was more common in the Andalusian armies, and heavy cavalry with body armour such as chainmail and helmets is less frequently depicted. None of the surviving images of helmets, which in some cases belonged to the Spangenhelme tradition - very similar to the one we have here- as can be guessed at from the allusion to «Frankish» weapons in some written sources (Soler del Campo, 2001, 345), show helmets equipped with either a nose guard or cheek piece, so they differ considerably from the Cercadilla relief. Other types, cited in the sources or recognisable in some images, are even less like the Cordoba relief. Similarly, aventails were a common part of Andalusian body armour, as the literary sources testify, and for this reason their absence from the Cordoba relief also distances it from the defensive armour of Al-Andalus.

The sword also displays major differences from Islamic swords, which often had trilobulate pommels of oriental influence (Bruhn de Hoffmeyer, 1972: 119 and Soler del Campo, 2001: 349, amongst others), or a spherical pommel, which became very widespread with the spread of late Roman prototypes; it was particularly common because it was considered the model used for the Prophet's sword (Alexander, 1999: 172). In addition, Andalusian blades had a central fuller, which is absent from the one depicted on the plaque from Cercadilla.

A comparison of the Cercadilla cavalryman with Mozarab iconography in Al-Andalus ${ }^{12}$ presents a different problem, because the vast majority of material examples disappeared at the time of the bitterest confrontations between the Almohads and the Almoravids. This deserves special attention since the centre of Christian worship of Cercadilla was heavily occupied by that community.

This makes it necessary to turn to the sumptuous miniatures contained in the Beatos, which include weapons of various kinds and are the major source of information we have on the subject. However, as the weapons in themselves are not a major source of interest in the miniatures, they are not shown in much detail, which in most cases makes it difficult to identify them with any precision.

We should also start by taking into account the sources of inspiration that were used by the Christians who lived in territory ruled by the Muslims when they portrayed a warrior. It is evident that the main sources for their subjects were the cavalry of the first emirate and later the caliphate. Only those who lived in the frontier territories would have been able to observe the Christian armies at first hand. They may also have been inspired by decorative features, either on buildings, objects of various kinds or in codices, for which the original sources could evidently be of very diverse influence, origin and even period.

Having said that, it is difficult to identify any images in the Mozarab miniatures that are remotely similar to the one that interests us here. The armed horsemen depicted in the codices are restricted almost entirely to the images of the four horsemen of the Apocalypse and the

10 Occupation of the site continued until the post-caliphate period (Fuertes, 2006), although on a very small scale which was, moreover, restricted to part of the site that was unconnected with the part where the plaque was found.

11 Amongst the many studies on Islamic iconography and weapons, see in particular Bruhn de Hoffmeyer, 1972; Nicole, 1976; Elgood, 1979; Zozaya, 2010; and above all the numerous works of A. Soler del Campo, which are essential for an understanding of the Hispanic medieval panoply (Soler del Campo, 1986, 1987a, 1987b, 1993, 1998, 1999, 2001, 2006, 2007 and 2011).

12 On this subject, see Soler del Campo, 1986 and 1999. Some aspects of weapons depicted in Mozarab images are also discussed in the works on the medieval panoply by Soler del Campo cited in the previous note. 
faithful horseman. A basic difference between the cavalryman of Cercadilla and the Mozarab miniatures, in addition to the actual stylistic differences arising from the different media used, is that the horsemen in the miniatures are shown with the head uncovered or, at most, with a headdress that might suggest a turban, the Spangenhelm being exceptional (Soler del Campo, 1999: 244-245). Thus the most significant element of the Cordoba plaque is missing. The same can be said of the chainmail and above all the sword, which, when it appears in the codices, usually has a central fuller and a circular pommel.

Thus on the basis of what we know today, the Cordoba plaque does not have a single element in common with Mozarab iconography that would allow us to associate the two.

Although the cavalryman's weapons clearly differ from those of the Roman era, they are related with those used in the Later Roman period ${ }^{13}$ and with their survival and evolution during Late Antiquity ${ }^{14}$, which influenced the Hispanic world to some extent. In this case, the helmet deserves special mention. Although the nose guard was not standard in Roman helmets, it did become widespread in later Roman times (James, 1986: 112). Both the cheek piece and, in particular, the nose guard and with it even the presence of the central plume/crest, enable the Cordoba cavalryman's helmet to be associated with the Spangenhelme and the ridge helmets ${ }^{15}$, particularly with the Dar al-Madinah, Berkasovo I and, above all, the Berkasovo II helmets ${ }^{16}$ - in the case of the latter very probably associated with the cavalry - in which the crest or plume was not unusual (fig. 8). It has been proposed that these helmets are types that derive, in the case of the Spangenhelme, from Danubian prototypes ${ }^{17}$ and, in the case of the ridge helmets, from a Persian model imported into Rome - especially in the case of the Berkasovo type - between the end of the third and the fourth century. The adoption of a helmet based on a Persian original should be seen as in character with the major oriental influence affecting the Court in the Tetrarchic period and, with it, other spheres of civil and military life in the Empire (James, 1986: 114 and 131 and 2004: 100) ${ }^{18}$, and in the context of new standardised forms that were introduced as a result of the new fabricae created under Diocletian for supplying weapons to the army (James, 1988). The model was developed and remained in use for a long time from then on, and various early medieval helmets that were widely used in Cen-

13 Of the many studies on Roman and Late Roman armour, see in particular Robinson, 1975; Connolly, 1988; Coulston, 1990; Dixon and Southern, 1992; Feugère, 1993; MacDowall, 1994 and 1995; Stephenson, 1999; Bishop and Coulston, 2006; Southern and Dixon, 1996; Quesada, 2008 and Alexandra and Gilbert, 2009.

14 Coulston, 1990; Feugère, 1993: 235-284; Lebedinsky, 2001.

15 Of the numerous studies on these helmets, their origin, types, development and survival see especially Klumbach, 1973 and James 1984 and 2004. Also, Robinson, 1975: 89-106; Feugère, 1994: 141-152; Southern and Dixon, 1996: 9196; Lebedinsky, 2001: 189-194; Bishop and Coulston, 2006: 210-216; Quesada, 2008: 301 and Dautova-Rusevjlan and Vujovic, 2010.

16 The detail included in the Cordoba plaque in the form of a shallow groove over the eye could be the projection of the rivet in the " $\mathrm{T}$ " of the nose guard, typical in these cases, or to emphasise the line of the eyebrow, coinciding in this respect particularly with the helmet from Dura Europos (Feugère, 1994, 149). This contrasts with the carving of the bowl of the helmet, in which there are no details of the separate parts, which is one of the main characteristics of these helmets, since they went from being made from a single piece to being assembled from several parts, thus making them easier to construct. Perhaps at the time the plaque was made, this characteristic was not considered a peculiarity worthy of attention, because it was normal in helmets of the period, or the model was closer to the ridge helmets, made by joining two lateral pieces, than the Spangenhelme, made from several sheets of metal.

17 Although there is evidence of the use of the Spangenhelm in the second century A.D. because it appeared on Trajan's column (James, 1986: 128-129 and Bishop and Coulton, 2004: 215), it did not become common until later.

18 Without doubt the model was already spreading in Constantine's time, as can be deduced from its depiction on Constantinian coins with a helmet that can be identified with the Berkasovo I type (Alföldi, 1932: n. 10), in which the cheek piece and nose guard have very probably been eliminated to show the imperial portrait. There is an example, very similar to the Dar al-Madinah type, with a nose guard on the Arch of Galerius in Thessalonica (James, 1986: 129 and MacDowall, 1994: 7). 


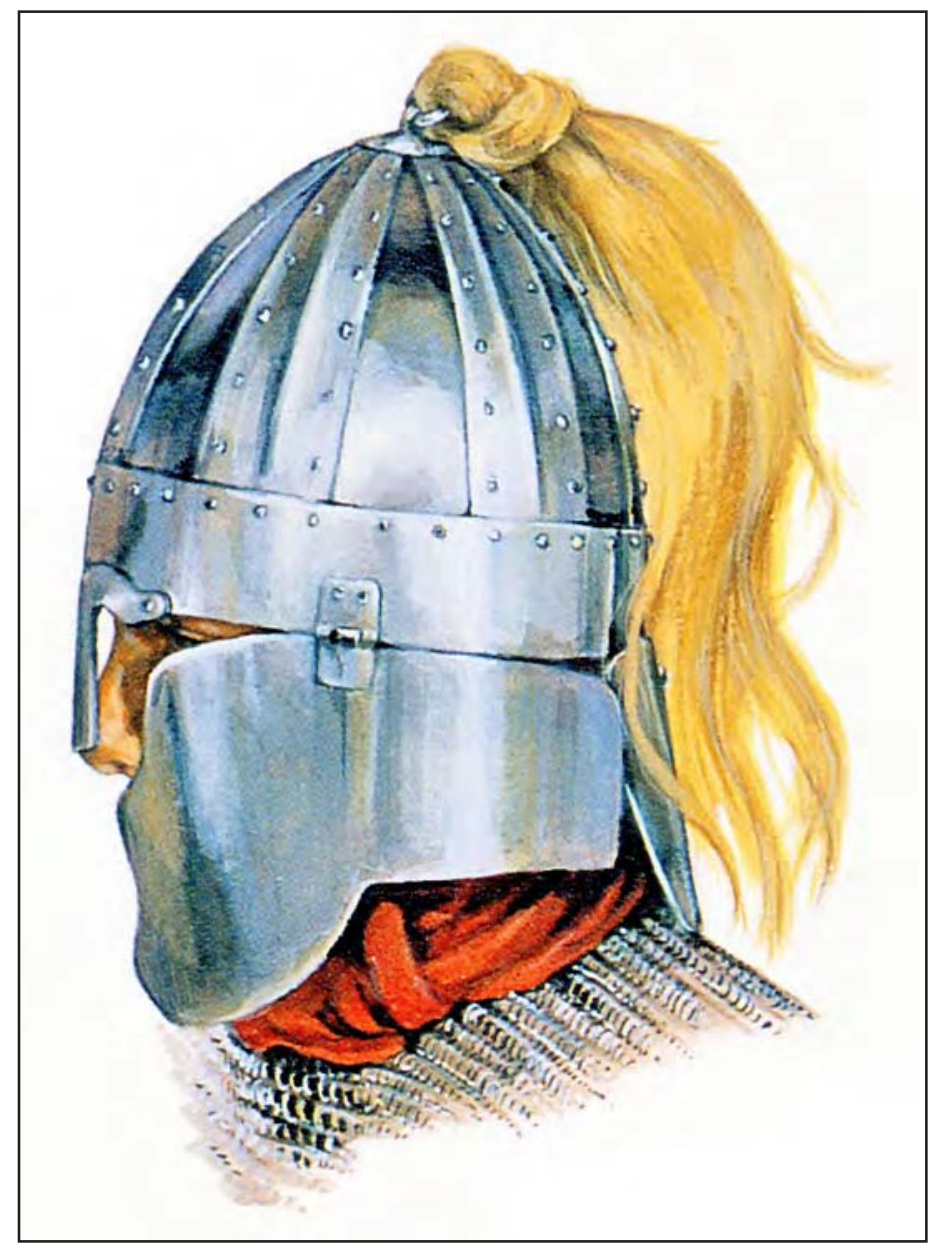

Figure 8. Recreation of the Dar al-Madinah helmet with plume (from: MacDowall, 1995, plate F.6).

tral Europe were derived from it (James, 1986: 124 and Bishop and Coulton, 2004: 215-216, amongst others).

The decoration of the helmet is also associated with the Late Roman tradition, not only because of its particular characteristics, but because the most elaborate and highly decorated helmets were reserved for the cavalry and officers (Klumbach, 1973, passim y James, 1986: 112).

What is of most interest to us here is that helmets of the Spangenhelm type continued to be used in the medieval Hispanic world (Soler del Campo, 2001, 349) ${ }^{19}$, which in turn perpetuated the Visigoth tradition of using the same helmet (Reinhart, 1947 and Soler del Campo, 2007: 154, amongst others). Although our sources of information for the Visigoth period panoply in general and helmets in particular are frankly scarce ${ }^{20}$, from what we do know, which is helped

19 With the presence of the nose guard in the early medieval Castilian-Leonine helmets, which was extended until it became a mask to protect almost the entire face (Soler del Campo, 2007: 166-167).

20 On Late Antique and Visigoth weapons in Hispania, poorly known mainly due to the lack of evidence for them, see in particular Zeiss, 1934; Sánchez Albornoz, 1938; Reinhart, 1947; Millán Crespo, 1994; Ardanaz, Rascón and Sánchez, 1998; Soler del Campo, 1998; 1999: 240; 2006: 125-126; 2007: 151-152; 2011: 341-343; Muñoz, 2003 and 2006 and Pérez Sánchez, 1989, for the operation of the army. Of the little that is known of the armour of this period, the scarcity of 


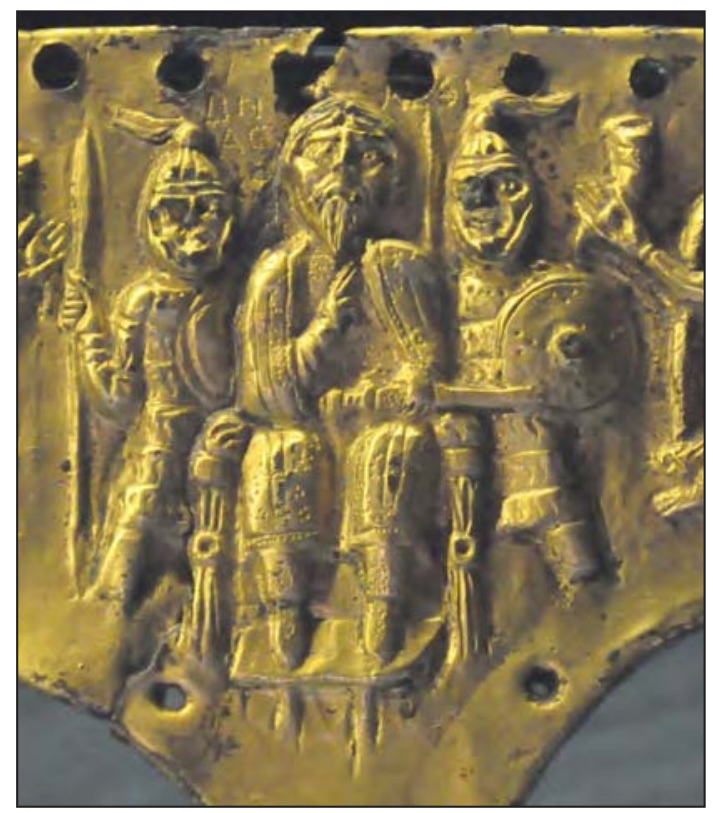

Figure 9. Detail of the Agilulf plaque (Bargello Museum, Florence) (Author's photograph).

met of the Spangenhelm type in which both plume and cheek pieces can be clearly seen and despite the fact that the face area is not preserved in a very good condition and, particularly in the one on the left of Agilulf, a nose guard would also appear to be present. In the same way, the horseman depicted on the silver plate in the treasure of Isola Rizza (fig. 10), dated to between the sixth and first half of the seventh centuries and of Lombard or Byzantine origin (Lebedinsky, 2001: 106), is wearing a Spangenhelm helmet with cheek piece, nose guard and plume.

Although the sword is depicted imprecisely, its main features at least can be also be associated with the Hispanic panoply of Late Antiquity. In particular, the sword can be related with the framea cited by Isidore of Seville (Etim. XVIII, 6.24), which was a double-edged sword, also referred to as a enormously by numismatics, also very rudimentary, it can be said that the continued use of these helmets, which allowed them to remain in use from the time they developed in the Later Empire to the panoply of the Early Middle Ages, a time when such distinctive identifying features as plumes, cheek pieces and nose guards continued to appear. In addition to the plume identified by Reinhart (1947: 125) it can also be suggested that nose guards were depicted in the images of Egica found on coins minted in Toledo, although in this case the portraits are so rudimentary it cannot be ruled out that they are in fact simplistic renderings of facial features.

A helmet with very similar characteristics to those displayed by the one worn by the Cercadilla cavalryman deserves special attention, as do those worn by the two members of the personal guard that flank the Lombard king Agilulf (590-616) in the plaque in the Bargello Museum of Florence (fig. 9) (Wessel, 1958). They each wear a hel-

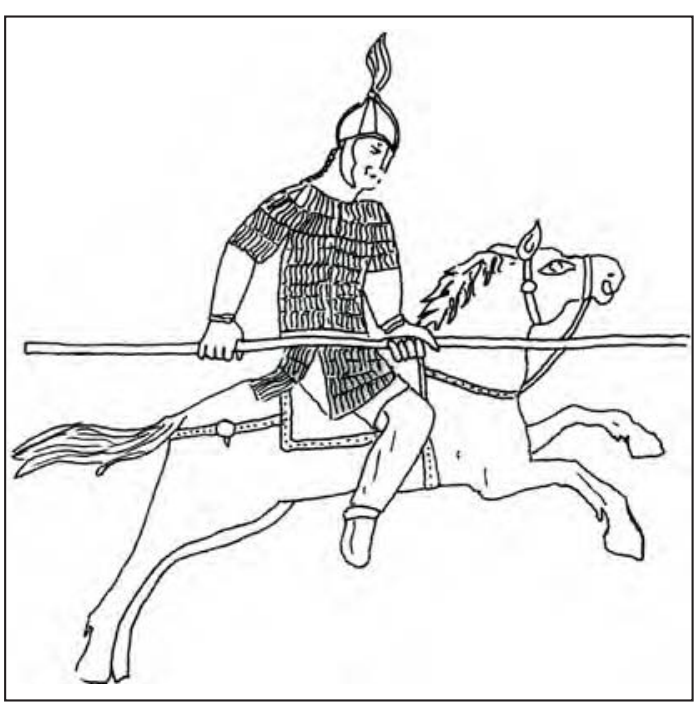

Figure 10. Cavalryman depicted on the plate from Isola Rizza (from: Lebedinsky, 2001: 106).

the elements that define the Cercadilla cavalryman is particularly striking: helmet, chainmail and long sword. This has to be blamed on the rarity of these items, which were doubtless restricted to a very small and select number of the military elite (García and Vivó, 2003: 183). This is supported by the fact that the only weapons usually found amongst the grave goods in Visigoth necropoleis are knives and daggers, defensive armour being completely absent (Ardanaz, Rascón and Sánchez, 1998: 411-412 y 428). 
spatha and documented in examples from Castiltierra (Segovia), Beja (Portugal), Guereñu (Alava) and Daganzo (Madrid). This type of sword coincides with the one depicted on the plaque in that it has no central fuller, which also differentiates it from the long swords of the ninth and tenth centuries. Only in the case of the sword from Beja (Schlunk and Hauschild, 1978: 157, taf. 50), dated around the first half of the fifth century, is part of the hilt preserved. It has a straight cross-guard with a square cross-section, which can also be associated with the sword shown in the Cordoba plaque, although it must be remembered that this is a very common type of cross-guard which was used from the Roman period until the end of the Middle Ages. The pommel of the Beja sword has not been preserved, but the type of pommel, also straight, seen in the Cercadilla cavalryman's sword, although not so long, is sometimes seen, as in the sword worn by Abraham in the well-known capital of San Pedro de la Nave ${ }^{21}$. In the same way chainmail, which was also used over a long period, was also used in the Visigoth period $^{22}$ and was, together with the helmet, a prestige item of very restricted use (Soler del Campo, 2007: 154).

Thus the exceptional nature of the panoply associated with the cavalryman, that is, the long sword, helmet and chainmail, allow him to be identified as a privileged member of the military elite of the Visigoth period, who displayed as a badge of prestige and social rank his select weapons and armour, which were characteristic of heavy cavalry - the main type of cavalry of the period ${ }^{23}$ - in the tradition of the later Roman Empire.

\section{CONCLUSIONS}

The characteristics of the cavalryman depicted on the Cordoba plaque, particularly the helmet, which can be associated with the widespread Spangenhelm and the ridge helmets and with the Dar al-Madinah and Berkasovo II helmets in particular and was very similar to those that appear on the Agilulf plaque and the Isola Rizza plate, allow the image to be dated to Late Antiquity. Although the shape of this type of helmet in the Tetrarchic period might suggest the continuation of a Late Roman tradition in the local area of Cordoba, the absence of a largescale and continuous presence of military contingents in the Cordoba of the Later Empire and, above all, the important development of this helmet in Central Europe after the fall of the Empire and during the Early Middle Ages, makes it more logical to assume that the iconography of the cavalryman was of external origin, particularly from the Visigoth world, in which, as has been said, the tradition of using the Spangenhelm continued. Furthermore, the proven tradition of using bronze plaques with armed cavalrymen in the bronzed reliefs of Late Antiquity and Medieval Europe, attested for the case that interests us here by the Stabio horseman and the bronze in the Badisches Landesmuseum of Karlsruhe, both dated to the seventh century, also point to this cultural and chronological context. By restricting ourselves to the chronological period when the Visigoths where physically present in Cordoba and, therefore, had greatest influence, we can propose a more precise date for the piece of between the second half of the sixth century and the seventh century.

${ }^{21}$ Fairly long straight pommels are not exceptional in contemporary Central European swords of the same period (Lebedinsky, 2001: 109-134). There is also a scramasax from Alcalá de Henares (Ardanaz, Rascón and Sánchez, 1998, 416-417).

22 According to C. Barrière-Flavy $(1902,131)$ chainmail would have been used by the Visigoths from the seventh century onwards, but the evidence is insufficient to adjust the dating, particularly taking into account that its use was due to the survival of an existing tradition.

23 And also taking into account that light cavalry, used for rapid skirmishes, was more common at a later date. 
Although the image is somewhat rudimentary, because of the lack of evidence dating to the period, the piece from Cordoba is an exceptional document for revealing a little more about the Visigoth panoply, about which so little is known.

\section{BIBLIOGRAPHY}

Alexander, D. (1999): «Dhu'l-Faqār and the legacy of the prophet, Mīrāth Rasūl Allāh», Gladius XIX, $157-188$.

Alexandra, A. and Gilbert, F. (2009): Lègionnaires, auxiliaires et fédérés sous le Bas-Empire romain, Paris.

Alföldy, A. (1932): «The Helmet of Constantine with the Christian Monogram», JRS 22, 9-23.

Arbeiter, A. and Noack-Haley, S. (1999): Christliche Denkmäler des frühen Mittelalters: vom 8. bis ins 11. Jahrhundert, Mainz.

Ardanaz, F; Rascón, S. and Sánchez, A. (1998): «Armas y guerra en el mundo visigodo». Los visigodos y su mundo. Arqueología, Paleontología y Etnología 4, 411-452.

Barrière-Flavy, C. (1902): «Le costume et l'armament du wisigoth aux Ve et VIe sècles», Revue des Pyrénees XXV, 125-143.

Barroso, R. and Morín, J. (2007): Regia Sedes Toledana. El Toledo visigodo a través de su escultura monumental, Toledo.

Baur, P.V.C.; Rostovtzeff, M.I and Bellinger, A.R. (1933 eds.): The Excavations at Dura Europos. Preliminary Report of the Third Season of Work, November 1929-March 1939, New Haven.

Bishop, M.C. and Coulston, J.C.N. (2006): Roman Military Equipment. From the Punic Wars to the fall of Rome, Oxford.

Bruhn De Hoffmeyer, A. (1972): Arms and Armour in Spain. A short survey, I. The Bronze Age to the end of the High Middle Ages, Madrid.

Caballero, L. and Mateos, P. (2007 eds.): Escultura decorativa tardorromana y altomedieval en la Península Ibérica, Madrid.

Canto, A. (2001): «Una espada de época omeya del s. IX d.C.», Gladius XXI, 183-192.

Connolly, P. (1988): The Roman Cavalryman, Oxford.

Coulston, J.C.N. (1990): «Late Roman Armour, 3rd-6th Centuries AD», Journal of Roman Military Equipment Studies I, 139-160.

Cruz Villalón, M. (1985): Mérida visigoda. La escultura arquitectónica y litúrgica, Mérida.

Dautova-Rusevjlan, V. and Vujovic, M. (2010): Late Roman Helmets from Jarak, Novi Sad.

Dixon, K. R. and Southern, P. (1992): The Roman Cavalry, London.

Elgood, R. (1979 ed.): Islamic Arms and Armour, London.

Feugère, M. (1993): Les Armes des Romains, Paris.

Feugère, M. (1994): Les Casques Antiques. Visages de la guerre de Mycènes à l'Antiquité tardive, Paris.

Fuertes, M ${ }^{a}$. C. (2006): «Córdoba durante el siglo XII. El abandono y ruina de los arrabales occidentales y su reconversión en espacio agrícola e industrial a través de las excavaciones de Cercadilla», El concepto de lo Provincial en el Mundo Antiguo. Homenaje a la Profesora Pilar León Alonso, Córdoba, 439-462.

Fuertes, Mª C. and Hidalgo, R. (2005). Guía Arqueológica de Cercadilla. Córdoba, Seville.

García de Castro Valdés, C. (2007): «La escultura arquitectónica en el área central de Asturias: tipos, tradiciones y tendencias», in: Caballero, L. y Mateos, P. (eds.) Escultura decorativa tardorromana y altomedieval en la Península Ibérica, Madrid, 85-132.

García Jiménez, G. and Vivó i Codina, D. (2003): «Santa julià de Raims y Puig Rom: dos ejemplos de yacimientos con armamento y equipamiento militar visigodo en el noreste peninsular», Gladius XXIII, 161-190.

Hidalgo, R. (1996): Espacio público y espacio privado en el conjunto palatino de Cercadilla: el aula central y las termas, Seville. 
Hidalgo, R. (2000): «Sobre la cristianización de la topografía de la Córdoba tardoantigua: el caso del Palacio de Cercadilla», Arqueología da Antiguedade na Península Ibérica. Actas III ${ }^{e r}$ Congresso de Arqueologia Peninsular Vol. 4, 741-754.

Hidalgo, R. (2002): «De edificio imperial a complejo de culto: la ocupación cristiana del palacio de Cercadilla», Espacios y usos funerarios en el Occidente romano, Córdoba, 343-372.

Hidalgo, R. and Fuertes Ma . C. (2001): «Córdoba, entre la Antigüedad Clásica y el Islam. Las transformaciones de la ciudad a partir de la información de las excavaciones de Cercadilla». Cuadernos Emeritenses 17, 223-264.

Hubert, J. (1968): La europa de las invasiones, Madrid.

Hyland, A. (1993): Training the Roman Cavalry. From Arrian's Ars Tactica, London.

James, S. (1986): «Evidence from Dura Europos for the Origins of Late Roman Helmets», Syria 63, 107-134.

James, S. (1988): «The fabricae: state arms factories of the Late Roman Empire», in: Coulston, J.C. (ed.), Military Equipment and the Identity of Roman Soldiers. Proceedings of the Fourth Roman Military Equipment Conference, BAR International Series 394, Oxford, 257-331.

James, S. (2004): The Excavations at Dura-Europos, Final Report VII: The Arms and Armours and other Military Equipment, London.

Klumbach, H. (1973 ed.): Spätrömische Gardehelme, Munich.

Lebedynsky, I. (2001): Armes et guerriers barbares au temps des grandes invasions (IV au VI siècle apr. $J-C$ ), Paris.

Luzón, J.M. and Sureda, J. (1997): Imperio y religión. Del mundo romano al prerrománico. Historia del Arte Español, vol. II, Barcelona.

MacDowall, S. (1994): Late Roman Infantryman AD 236-565, Oxford.

MacDowall, S. (1995): Late Roman Cavalryman AD 236-565, Oxford.

Millán Crespo, J.A. (1994): «Análisis de un elemento de vestuario militar altomedieval peninsular», IV Congreso de Arqueología Medieval Española, vol. III, 969-978.

Muñoz, R. (2003): El ejército visigodo. De los orígenes a la batalla de Guadalete, Madrid.

Muñoz, R. (2006): «El ejército visigodo», Aproximación a la Historia Militar de España vol. 1, Madrid, 81-97.

Nicole, D. (1976): Early Medieval Islamic Arms and Armour, Madrid.

Ortiz, L. (2003): «Los Mozárabes de Córdoba. Una aproximación preliminar a la necrópolis de Cercadilla», Arte, Arqueología e Historia 10, 79-84.

Pérez Sánchez, D. (1989): El ejército en la sociedad visigoda, Salamanca.

Quesada, F. (2008): Armas de Grecia y Roma, Madrid.

Reinhart, W. (1947): «Los yelmos visigodos», AEspA XX, 122-125.

Ripoll, G. (1998): Toréutica de la Bética (siglos VI y VII d.C.), Barcelona.

Robinson, H.R. (1975): The Armour of Imperial Rome, London.

Rostovtzeff, M.I. et alii (1952): The Excavations at Dura Europos. Preliminary Report of the Ninth Season of Work, 1935-36, New Haven.

Sánchez, J. (2006): Elementos arquitectónicos de época visigoda en el Museo Arqueológico de Córdoba: arquitectura y urbanismo en la Córdoba visigoda, Córdoba.

Sánchez Albornoz, C. (1938): «La caballería visigoda», Witschaft und Kultur. Festschrift zum 70 Geburtstag von Alfons Dopsch, Viena, 92-108.

Schlunk, H. and Hauschild, Th. (1978): Hispania Antiqua. Die Denkmäler der früchristlichen und westgotischen Zeit, Mainz am Rheim.

Soler del Campo, A. (1986): «Sistemas de combate en la iconografía mozárabe y andalusí Altomedieval», Boletín de la Asociación Española de Orientalistas 12, 61-87.

Soler del Campo, A. (1987a): El armamento medieval hispano, Madrid.

Soler del Campo, A. (1987b): «El armamento en época omeya», Madrid del siglo IX al I, Madrid, 171188.

Soler del Campo, A. (1993): «Notas sobre la evolución de los modelos de armamento adoptados en Al-Andalus (siglos X-XIV)», IV Congreso de Arqueología Medieval Española, vol. I, Alicante, 97-115.

Soler del Campo, A. (1998): «La transición del armamento en Al-Andalus desde época preislámica», Ruptura o continuidad. Pervivencias preislámicas en Al-Andalus, Mérida, 65-81. 
Soler del Campo, A. (1999): «Armas, arreos y banderas en las miniaturas del códice», Codex biblicus legionensis: veinte estudios, León, 239-252.

Soler del Campo, A. (2001): «El armamento omeya peninsular», El esplendor de los omeyas cordobeses, Barcelona, 344-349.

Soler del Campo, A. (2006): «El armamento en el medievo hispano», Aproximación a la Historia Militar de España vol. 1, Madrid, 125-141.

Soler del Campo, A. (2007): «El equipamiento militar en el medievo», in: Casado Quintanilla, B. and de la Iglesia Duarte, J. I. (eds.), La guerra en la Edad Media. Logroño, 147-190.

Soler del Campo, A. (2011): «El armamento en torno al 711 dj.», 711. Arqueología e Historia entre dos mundos, Zona Arqueológica 15, vol. II, Alcalá de Henares, 341-346.

Southern, P. and Dixon, K. R. (1996): The Late Roman Army, London.

Stephenson, I.P. (1999): Roman Infantry Equipment, the Later Empire, Stroud.

Vidal, S. (2005): La escultura hispánica figurada de la Antigüedad Tardía (siglos IV-VII), Murcia.

Vidal, S. (2007): «La transmisión iconográfica en la escultura hispánica de la Antigüedad Tardía. Vigencia y discontinuidad de modelos», in: Caballero, L. and Mateos, P. (eds.) Escultura decorativa tardorromana y altomedieval en la Península Ibérica, Madrid, 11-46.

Vizcaíno, J. (2008): «Early Byzantine lamellar armour from Carthago Spartaria (Cartagena, Spain)», Gladius XXVIII, 195-210.

Wessel, K. (1958): «Ikonographische Bemerkungen zur Agilulf-Platte», Festschrift Johannes Jahn 22 November 1957, Leipzig, 61-67.

Zeiss, H. (1934): Die grabfunde aus dem spanischen Westgotenreich, Berlín-Leipzig.

Zozaya, J. (2010): «Los señores de la guerra», Cuadernos de Madinat al-Zahra 7, 43-63.

Recibido: 02/12/2011

Aceptado: $12 / 03 / 2012$ 
